\title{
RECURRENT EXPOSURE OF PATIENTS WITH CHRONIC CONDITIONS IN A SMALL PRIVATE MEDICAL CENTER
}

\author{
Olga Irina Girjoaba*
}

Academica Medical Center, Bucharest, Romania

\begin{abstract}
One of the topics recently proposed by the IAEA on the medical exposure to ionising radiation is the recurrent exposure of patients with chronic conditions, at short intervals, using highly irradiating procedures such as CT examinations and interventional cardiological and non-cardiological procedures. An IAEA study presents that the number of patients who have received cumulative effective doses (CED) in the 50-50o $\mathrm{mSv}$ range, over a period of 1-5 years, has increased a lot in recent years. Based on these considerations, we performed a study referring to the evaluation of CED due to recurrent CT exposures, performed with a CT unit GE Bright Speed 16, in a private medical center focused on the follow-up on the evolution of malignant diseases of the patients, during the treatment process. In our study, we used a local electronic system for individual registration of medical exposures, that provides information about patient data and also about scan parameters, including total dose-length product (DLP), for every exam performed. Based on this information, CED was evaluated for patients with recurrent exposure. We analyzed a patient group of 350 persons randomly chosen, that performed 500 CT examinations, 52 patients from the total number (14.8\%) presenting recurrent exposures over a period of 1-5 years. All of the patients who performed recurrent exposure received a CED of more than $100 \mathrm{mSv}$. Most of the patients from the study are over 50 years old and most frequently only 2-4 exams per patient are performed, but there are also 6 patients who were scanned 8-10 times over a period of 1-5 years. For many patients, the time interval between consecutive scans is less than one year, meaning that an important radiation dose is received by the patient within a short time interval. To have a real image of CED for every patient from Romania, it is necessary to create an electronic system at the national level for individual registration of medical exposures. This electronic system must be available to every physician, from everywhere in the country and the ionising radiation exams must be indicated after a good analysis of information concerning the CED of every patient.
\end{abstract}

Keywords: Cumulative effective doses (CED), CT examinations, electronic system for individual registration, medical exposure to ionising radiation, recurrent exposure of patients

\section{INTRODUCTION}

Publications in the scientific literature have shown that patients undergoing diagnostic and interventional radiological procedures can receive cumulative effective doses (CED) in the range of 50-500 mSv. The patients who receive such high cumulative radiation doses typically need radiological imaging exams for multiple clinical indications, for follow-up of malignant disease or chronic conditions. An IAEA study [1] presented data from 2.5 million patients, from different European countries, who underwent imaging (mostly CT) procedures over periods between 1 and 5 years in different hospitals. It was observed that the number of patients with CED $\geq 100 \mathrm{mSv}$ is much higher than previously known, most conservative estimates showing that at least $0.5 \%$ of patients who undergo CT exams are likely getting radiation dose over $100 \mathrm{mSv}$ in a single year. About 10 to $20 \%$ of these patients are below 50 years of age. This being a relatively new observation, there is a need to do further work to fully understand the extent of recurrent exposures, the doses involved and whether any of these exposures could be avoided or further optimized.

Based on these considerations, we performed a study referring to the evaluation of CED due to recurrent CT exposures, performed with a CT unit GE Bright Speed 16, in a small private medical center, Academica Medical Centre, focused on the follow-up on the evolution of malignant diseases of the patients, during the treatment process.

Justification of these recurrent exposures is in accordance with the clinical protocol for every type of treatment that impose, as a regular control, a CT exam 6 months after surgery, or a CT exam every 3 months for the verification of response of the chemotherapy, or in case of immunization treatment for breast cancer or melanoma, a CT exam every 3 weeks.

\section{METHODS}

Academica Medical Centre is a small private medical center, the total annual number of CT exams performed there being around 2500, which represents

\footnotetext{
*olga.garjoaba@academica-medical.com,olga_guguianu@yahoo.com
} 
a small number in comparison with the number of patients from radiological departments of emergency or county hospitals.

In our study, we used a local electronic system for individual registration of medical exposures which provides information about patient data (name, individual identification number, age, gender, height, weight) and also information about every performed exam, including the date of exam, type of examination, anatomical region, if substance of contrast is used, scan parameters, dose index CTDIvol and dose-length product (DLP) for every scan sequence, total DLP.

We analyzed a patient group of 350 persons randomly chosen who performed 500 CT examinations, 52 patients from the total number (14.8\%) presenting recurrent exposures over a period of 1-5 years. The patients were divided into groups depending on age and number of performed CT exams in a period of 1-5 years. At the same time, the data were analysed taking into account the time interval between consecutive scans and also the investigated anatomical region.

Knowing the conversion coefficients from doselength product (DLP) to effective dose [2] for every region of the body scanned, we evaluated the cumulative effective doses (CED). Some clinical cases with CED more than $100 \mathrm{mSv}$ are presented below.

\section{RESULTS}

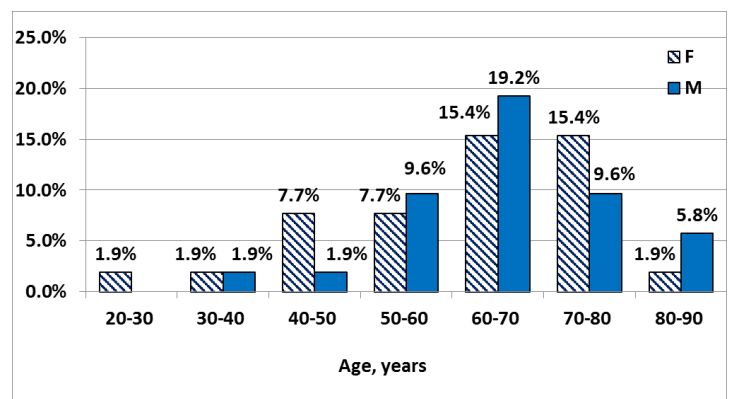

Figure 1. The percentage distribution of patient numbers depending on the age and gender groups

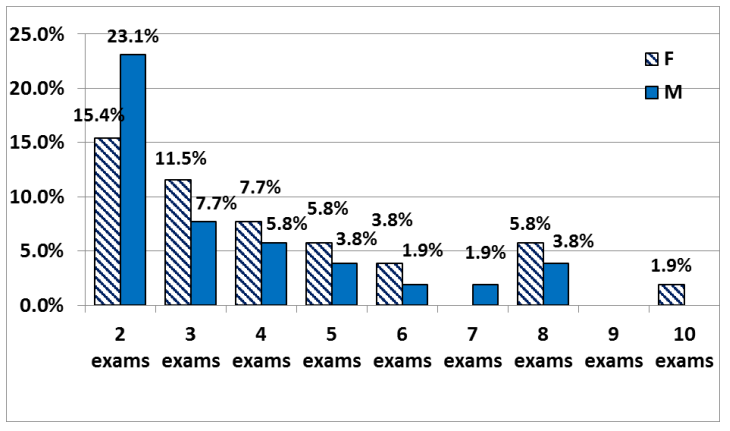

Figure 2. The percentage distribution of patient numbers depending on the performed exams number

For the group with recurrent exposure, composed of 27 women and 25 men, the total number of scans was 198 , which represents $39.6 \%$ of the total exam number. For this group, the percentage distribution of patient numbers depending on the age and gender groups and the percentage distribution of patient 192 numbers depending on the performed scans (exams) are presented in Figure 1 and Figure 2. Most of them (76.9\%) were between 50 and 80 years old, the number of men being bigger for 50-70 years old. The number of women was bigger for 40-50 and 70-80 years old. 37 patients, which represents $69.3 \%$, were scanned $2-4$ times, but there were also 6 patients who were scanned 8-10 times in a period of 1-5 years. A percentage of $57.5 \%$ of the total number of exams was performed in a time interval of less than one year. All of the patients who performed recurrent exposure received a CED more than $100 \mathrm{mSv}$.

The number of recurrent exams depending on the time interval between consecutive scans, counted for each patient after the first exam performed at Academica Medical Center, is presented in Figure 3 . The majority of recurrent CT exams (82.3\%) were performed within a time interval of 1 month - 13 months between consecutive scans. The most frequent time interval was 5 months, but 2 months and 1 year were also very used intervals between consecutive scans.

Concerning the percentage distribution of exams number depending on the investigated anatomical region, this is shown in Figure 4. Most recurrent performed CT exams were trunk scans (thoraxabdomen-pelvis) (39.9\%), followed by thorax-abdomen scans and head-thorax-abdomen (11.6\%), thorax scans and abdomen-pelvis scans (9.1\%).

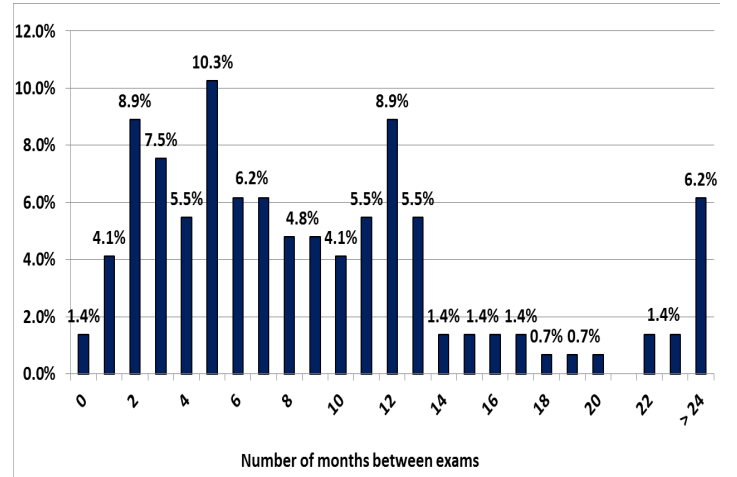

Figure 3. The percentage distribution of recurrent exams number depending on the time interval between consecutive exams

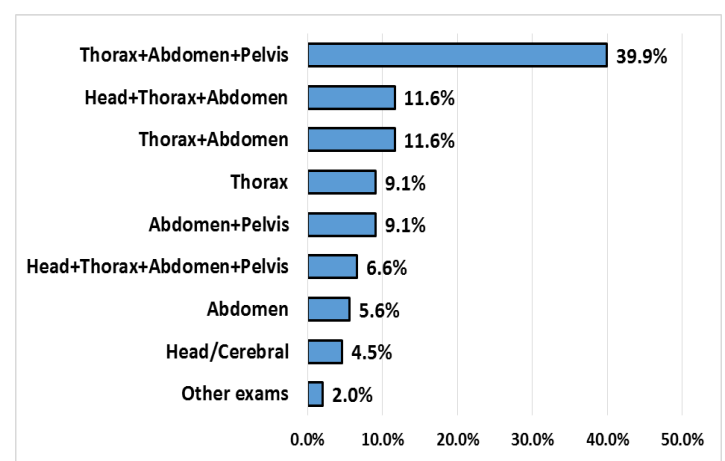

Figure 4. The percentage distribution of exams number depending on the investigated anatomical region

In some clinical cases, patients who received a CED that exceed $100 \mathrm{mSv}$, are presented below, in Table 1 . 
The age of the patients written in the table represents the age at the beginning of the treatment and the CT follow-up. Having included CT scans of different anatomical regions (exam type), in the table is written the number of performed CT exams for every exam type. The cumulative effective doses are evaluated based on the DLP and taking into account the specific conversion coefficients for every region of the body scanned [2].

These clinical cases were chosen because the CED exceeds $200 \mathrm{mSv}$, or the time interval between consecutive scans is very short, or the age of the patient is below 50 years. The youngest patient was 33 years old and received $103 \mathrm{mSv}$ in two and a half years. The shortest time period was 5 months for 3 trunk exams with $128 \mathrm{mSv}$ for another patient. The highest CED was $402 \mathrm{mSv}$ and was received by the patient in a short time period - only 16 months.

Table 1. Clinical cases, patients who received a CED that exceeds $100 \mathrm{mSv}$

\begin{tabular}{|c|c|c|c|c|c|}
\hline$\underset{t}{\text { Patien }}$ & $\begin{array}{l}\text { Gende } \\
\mathbf{r}\end{array}$ & $\begin{array}{c}\text { Age } \\
\text { (year) }\end{array}$ & $\begin{array}{c}\text { Number of } \\
\text { performed CT exams } \\
\text { and anatomical } \\
\text { region }\end{array}$ & $\begin{array}{c}\text { Total } \\
\text { time } \\
\text { perio } \\
\mathbf{d}\end{array}$ & $\begin{array}{l}\text { CED - } \\
\text { (mSv) }\end{array}$ \\
\hline $\begin{array}{l}\text { Patient } \\
\text { A }\end{array}$ & Male & 55 & 8 exams Head+Trunk & $\begin{array}{l}6 \text { years } \\
\text { and } 5 \\
\text { months }\end{array}$ & 382.63 \\
\hline $\begin{array}{l}\text { Patient } \\
\text { B }\end{array}$ & Male & 49 & 8 exams Trunk & $\begin{array}{l}2 \text { years } \\
\text { and } 7 \\
\text { months }\end{array}$ & 345.60 \\
\hline $\begin{array}{l}\text { Patient } \\
\text { C }\end{array}$ & Female & 74 & $\begin{array}{l}1 \text { exam Abdomen+Pelvis, } \\
1 \text { exam Head, } \\
6 \text { exams Trunk }\end{array}$ & 2 years & 300.90 \\
\hline $\begin{array}{l}\text { Patient } \\
\text { D }\end{array}$ & Female & 64 & $\begin{array}{l}3 \text { exams } \\
\text { Abdomen+Pelvis, } \\
2 \text { exams Abdomen, } \\
2 \text { exams } \\
\text { Thorax+Abdomen, } \\
1 \text { exam Trunk }\end{array}$ & $\begin{array}{l}4 \text { years } \\
\text { and } 11 \\
\text { months }\end{array}$ & 275.03 \\
\hline $\begin{array}{l}\text { Patient } \\
\text { E }\end{array}$ & Female & 56 & $\begin{array}{l}5 \text { exams } \\
\text { Head+Thorax+Abdomen, } \\
1 \text { exam Head+Trunk }\end{array}$ & $\begin{array}{l}4 \text { years } \\
\text { and } 2 \\
\text { months }\end{array}$ & 239.12 \\
\hline $\begin{array}{l}\text { Patient } \\
\text { F }\end{array}$ & Male & 48 & 3 exams Trunk & $\begin{array}{c}5 \\
\\
\text { months }\end{array}$ & 128.48 \\
\hline $\begin{array}{c}\text { Patient } \\
\text { G }\end{array}$ & Male & 33 & 5 exams Thorax & $\begin{array}{l}2 \text { years } \\
\text { and } 6 \\
\text { months }\end{array}$ & 103.35 \\
\hline $\begin{array}{c}\text { Patient } \\
\text { H }\end{array}$ & Female & 47 & $\begin{array}{l}\text { exams } \\
\text { Thorax+Abdomen, } \\
2 \text { exams } \\
\text { Head+Thorax+Abdomen }\end{array}$ & $\begin{array}{l}1 \text { year } \\
\text { and } 4 \\
\text { months }\end{array}$ & 402.78 \\
\hline $\begin{array}{l}\text { Patient } \\
\text { I }\end{array}$ & Male & 70 & 5 exams Trunk & 1 year & 219.13 \\
\hline $\begin{array}{c}\text { Patient } \\
\mathrm{J}\end{array}$ & Female & 52 & 8 exams Trunk & $\begin{array}{l}3 \text { years } \\
\text { and } 4 \\
\text { months }\end{array}$ & 357.60 \\
\hline $\begin{array}{c}\text { Patient } \\
\mathrm{K}\end{array}$ & Male & 58 & $\begin{array}{l}5 \text { exams Trunk } \\
1 \text { exam Thorax+Abdomen }\end{array}$ & 5 years & 256.95 \\
\hline
\end{tabular}

\section{Discussion}

The actual study confirms the situation of recurrent exposures to ionising radiation presented by the IAEA study [1], concerning the frequency of CT scans with high values for CED. The frequency of recurrent exposure in this small private center is high, taking into account the percent observed in the IAEA study, but at the same time, it is justified because, generally, the patients with chronic diseases (cancer) follow their treatment's evolution in private clinics much more than in radiological departments of emergency or county hospitals.

Most of the patients from the study are more than 50 years old, peaking around 60-70 years old and most frequently have undergone only 2-4 exams. But, for many patients, the time interval between consecutive scans is less than one year, which means an important radiation dose is received by the patient in a short time interval. The tissues do not have enough time to repair the damage caused by the ionising radiations, which could lead to developing other heath injuries. Another aspect is regarding the most frequent exam type that is for trunk (thorax+abdomen+pelvis), where the majority of risk organs are located.

The importance of a strong justification for every CT scan is more than evident. The physicians need not only referral guidelines for medical imaging as is specified in Council Directive 2013/59/Euratom [3], but also an electronic system that can provide information about every medical exposure performed by each patient, taking into account the radiation doses.

The existence of an electronic system for individual registration of medical exposures at Academica Medical Center has allowed the evaluation of the CED, but this happens only at the local level. To have a real image of CED for every patient from Romania, it is necessary to create an electronic system at the national level for individual registration of medical exposures. This electronic system must be available to every referrer, from everywhere in the country and the ionising radiation exams must be indicated after a good analysis of information concerning the CED of every patient. Regarding the radiation protection of patients, the referrers must analyze, for every patient, the possibility of using non-ionising imaging modalities (MRI, ultrasound) instead of CT exams. Taking into account the high values of CED received by the patients as in our study, optimization of CT exams is needed using the concept of diagnostic reference levels.

\section{CONCLUSION}

To have a real image of CED for every patient from Romania, it is necessary to create an electronic system at the national level for individual registration of medical exposures. This electronic system must be available to every physician, from everywhere in the country and the ionising radiation exams must be indicated after a good analysis of information concerning the CED of every patient.

\section{REFERENCES}

1. Summary of the IAEA Technical Meeting on Radiation Exposure of Patients from Recurrent Radiological Imaging Procedures, IAEA, Vienna, Austria, 2019. Retrieved from: https://www.iaea.org/sites/default/files/19/04/rpoptm_summary_final.pdf

Retrieved on: Jul. 7, 2019

2. European Guidance on Estimating Population Doses from Medical X-Ray Procedures, Radiation Protection no. 154, European Commission, Luxembourg, Luxembourg, 2008, pp. 23-43.

Retrieved from:

https://ec.europa.eu/energy/en/topics/nuclearenergy/radiation-protection/scientific-seminars-andpublications/radiation-protection-publications Retrieved on: Jul. 10, 2019

3. The Council of European Union. (Dec. 5, 2013). Council Directive 2013/59/EURATOM. Laying down basic safety standards for protection against the dangers arising from exposure to ionising radiation, and repealing Directives 89/618/Euratom, 
O. Girjoaba, Recurrent exposure of patients with chronic conditions, RAP Conf. Proc., vol. 4, 2019, 191-194

90/641/Euratom, 96/29/Euratom, 97/43/Euratom

and 2003/122/Euratom.

Retrieved from: https://eur-

lex.europa.eu/LexUriServ/LexUriServ.do?uri=OJ:L:20

14:013:0001:0073:EN:PDF

Retrieved on: Jul. 11, 2019 